Darja Premrl

UDK: 37.064.2:811.133.1'243

Gimnazija Piran

darjapremrl@gmail.com

\title{
Karmen Pižorn
}

Pedagoška fakulteta Univerze v Ljubljani

karmen.pizorn@pef.uni-lj.si

\section{VLOGA UČITELJA PRI UČNI USPEŠNOSTI UČENCA: PRIMER FRANCOŠČINE KOT TRETJEGA TUJEGA JEZIKA}

Učno uspešnost $\mathrm{v}$ slovenskem šolskem sistemu merimo $\mathrm{z}$ ocenami na petstopenjski lestvici in je rezultat mnogih dejavnikov, ki jih Puklek Levpušček in Zupančič (2009) uvrščata v več sklopov. Med poglavitnimi so inteligentnost (najboljša povezanost med inteligentnostjo in učno uspešnostjo je $\mathrm{v}$ osnovni šoli in se $\mathrm{v}$ nadaljnjem izobraževanju znižuje), osebnostne poteze, med katerimi vestnost (delavnost, natančnost, skrbnost) in odprtost (bistrost, domišljija, ustvarjalnost, želja po učenju) učencev najbolje napovedujeta učne dosežke, učna motivacija in tudi socialni kontekst, kamor avtorici uvrščata vedênje do otroka njemu pomembnih oseb, družinsko okolje, učiteljevo vedênje v razredu.

Učenec torej ni v celoti sam odgovoren za svojo učno uspešnost, saj mu pri tem lahko pomagajo učitelji, njegovi starši, sošolci in prijatelji. »Posledice ocenjevanja za učence so spoznavne, čustvene in motivacijske. Pri prvih gre za spoznavno raven učenja in pouka, pri drugih za strese, čustveno napetost (ki je pri določenem odstotku učencev tako močna, da ovira normalno umsko delovanje), pri tretjih pa za postopno prevladovanje zunanje motivacije nad notranjo - učenje za ocene, ne iz interesa ali želje po znanju « (Marentič Požarnik in Peklaj 2002: 32). Ob zavedanju teh dejstev, se moramo vprašati, kaj torej lahko naredim kot učitelj, da bo učenec znanje sprejel kot vrednoto, da se bo učil, ker se želi, ker ga snov zanima? Katere didaktične, vzgojne in druge prijeme, ki jih imam kot učitelj na razpolago, naj uporabim, preden izpostavim učenca testni situaciji in mu dodelim določeno oceno? Postavljajo se tudi mnoga druga vprašanja, kot: zakaj ga bom ocenil, kako ga bom ocenil in kaj sporoča pridobljena ocena, meni kot učitelju in kaj učencu?

\section{ZAGOTOVITI KAKOVOSTEN ODNOS MED ŠOLO IN STARŠI}

Smiselno je najprej poskrbeti za kakovosten odnos med šolo in starši, s ciljem doseči optimalen razvoj posameznega učenca. Kot navajajo Kalin idr. (2009: 6981) ter Grolnick in Slowiaczek (1994: 238) kažejo študije, da aktivno vključevanje družine prinaša boljše učne dosežke, torej na splošno pozitivno prispeva k učenju 
in učni uspešnosti učencev, pozitivno vpliva na razvoj samopodobe in samozavesti, skratka pozitivno vpliva na učenčevo duševno zdravje, na učenčev čustveni in socialni razvoj. Učenci staršev, ki sodelujejo s šolo, se v šoli dobro počutijo, so redno prisotni pri pouku, opravljajo domače naloge, imajo pozitivna stališča do šole, izražajo močna hotenja na področju izobraževanja in redkeje opuščajo šolanje (Kalin idr 2009: 73).

Da bi se čim bolj približali prej opisanemu idealu učenca, mora učitelj prevzeti pobudo in spodbujati starše $\mathrm{k}$ vključevanju v šolsko delo, najbolje kar s konkretnimi predlogi. Izvedenih je bilo namreč več raziskav, ki dokazujejo, da veliko staršev kljub interesu za šolo, ne ve, kako bi sodelovali (Kalin 2009: 74). Obstaja več načinov starševskega vključevanja v šolo (Grolnick in Slowiaczek 1994 in Coleman 1998 v Kalin idr. 2009: 78). Coleman predlaga idealen model, ki vključuje tri oblike sodelovanja med učitelji in starši, namenjene spodbujanju učenja pri učencih: inkluzivni model učenja, ki staršem omogoča svobodno vključevanje $\mathrm{v}$ življenje in delo na šoli in v razredu; dosledno učiteljevo modeliranje sodelovalne prakse v oddelku, ki učencem zagotavlja veliko priložnosti za učenje, visoka učiteljeva pričakovanja in stalno spremljanje napredka; in razvijanje aktivnosti, ki se nanašajo na najširši razvoj šole, kjer je na prvem mestu ustrezna šolska klima in kultura, za kar so potrebni aktivno sodelovanje, timsko delo, razgovori, in sicer na ravni šole kot tudi med učitelji in starši.

Gonzalez-DeHass (2005, v Kalin idr. 2009: 73-74) je opravila primerjalno analizo raziskav in ugotovila pomembno pozitivno povezanost med vključevanjem staršev in motivacijo učencev: motivacija učencev spodbuja vključevanje staršev, vključenost staršev prispeva $\mathrm{k}$ učenčevemu samouravnavanju učenja in dejanski zaznavi in samoocenjevanju lastnih sposobnosti za učenje kjer Grolnick in Ryan (1989) poudarjata starševski pomen spodbujanja avtonomije in odgovornosti pri otrocih (Grolnick in Slowiaczek 1994: 250); zagotavlja občutek varnosti in povezanosti, ter pomaga učencem ponotranjiti vrednote izobraževanja. Končni rezultati študije kažejo, da pri večji vključenosti staršev učenci poročajo o večjem trudu, koncentraciji in prisotnosti, bolj so zainteresirani za učenje in dosegajo višje kompetence, ter $\mathrm{v}$ večji meri prevzemajo osebno odgovornost za svoje učenje. Starši s svojim zanimanjem za otrokovo izobraževanje, spodbujajo, da učenci oblikujejo ciljno orientirano učenje, kar pomeni da $v$ večji meri iščejo zahtevne naloge, da vztrajajo pri doseganju akademskih ciljev in da doživljajo zadovoljstvo pri svojem šolskem delu. Do podobnih ugotovitev sta prišli tudi Grolnick in Slowiaczek (1994: 247-250).

$\mathrm{Na}$ tem mestu velja omeniti tudi izsledke raziskav o odzivih staršev na dobre oziroma slabe ocene, kot obliki zunanje nagrade, ki kažejo, da zunanje nagrajevanje negativno vpliva na ocene učencev in na njihov trud v šoli. Ginsburg in Bronstein (1993: 1470-1472) ugotavljata, da starševsko nagrajevanje ne spodbuja učencev $\mathrm{k}$ učenju za znanje, torej notranje motivacije, saj je povezano s slabšimi ocenami in slabšimi dosežki. Več kot je zunanjega nagrajevanja, bolj učenci iščejo zunanje kriterije za lastno učenje. Na podlagi zunanjih nagrad nato vrednotijo svoj (ne)uspeh v šolskih situacijah. Raziskovalki nadalje ugotavljata, da tudi učitelji opažajo pri zunanje nagrajevanih učencih manj motivacije, manj zadovoljstva pri delu v šoli in primanjkljaj na področju vztrajnosti. Avtorici trdita, da starše- 
vska spodbuda pozitivno vpliva na razvoj notranje motivacije. Starši naj pohvalijo svoje otroke za dobro opravljeno delo in njihove sposobnosti. »Učitelji in starši bi morali (o)ceniti razvoj znanja in spretnosti, ki so pomembnejše od posameznega testa $\lll$ (Gardner 2000).

\section{Z USTREZNO POVRATNO INFORMACIJO UČITELJ RAZVIJA POZITIVEN ODNOS UČENCEV DO LASTNIH UČNIH ZMOŽNOSTI}

Puklek Levpušček in Zupančič (2009: 66) izhajajoč iz Bandurinove teorije samoučinkovitosti (posameznikova prepričanja o sebi so pomembni dejavniki učne uspešnosti) zaključujeta, da je pomembno, da učitelj s svojim delom v razredu »izvaja programe, ki so usmerjeni v razvijanje pozitivnega odnosa učencev do lastnih učnih zmožnosti« (Puklek Levpušček in Zupančič 2009: 67), pri čemer je pomembno na primeren način učencu posredovati resnično povratno informacijo. »Povratno informacijo je treba oblikovati tako, da na otroka deluje spodbudno, mu omogoča pozitivno samopotrdilo ali pa mu vzbuja zaupanje v njegove zmožnosti za izboljšanje« (Razdevšek-Pučko 1999: 149). Učitelj bo pri delu uspešnejši, če bodo pri vzgoji sodelovali tudi starši v domačem okolju, seveda na podlagi kvalitetnega medsebojnega sodelovanja.

Povratno informacijo običajno predstavljajo rezultati preverjanja znanja, vendar je smiselno nuditi učencem sprotne povratne informacije, pisne in ustne, ki zadevajo vsakodnevno delo v razredu. »Dobra povratna informacija vpliva na proces učenja s tem, da utrdi pravilne (zaželene) oblike učenja (védenja) tako, da učenec spozna in po možnosti sam ugotovi pravilnosti oziroma nepravilnost, hkrati pa dobi tudi podrobno informacijo o tem, katere sestavine njegovega dela so dobre ali pravilne, katere pa ne, skupaj s tem pa mora dobiti še napotke, kako naj svoje delo (učenje) izboljša, da se bo približal standardom, ki izhajajo iz narave problema oz. iz narave dela« (Razdevšek-Pučko 1999: 148-149). Učitelj s povratno informacijo učencem pove, kaj delajo prav in kaj narobe. Prav je, da jih seznani tudi z izvorom napake, $z$ namenom, da učenci napake ne bi ponovili, saj pogosto niso slučajne, ampak izhajajo iz napačnega razumevanja ali iz napačne predpostavke. Učitelj mora paziti, da se dajanje povratnih informacij ne razvije $\mathrm{v}$ odvisnost, zanj pa $\mathrm{v}$ instrument nadzora, dokazovanja moči in oblasti, torej neke vrste rituala nagrajevanja ali kaznovanja (prav tam).

Funkcija dobre učiteljeve sprotne povratne informacije je koristna predvsem učencu, saj mu »omogoča nadzor nad dosežki in mu pomaga pri usmerjanju miselnih procesov $\mathrm{k}$ ciljem. $\mathrm{V}$ primeru napak daje povratna informacija potrebne usmeritve za spreminjanje procesa učenja. Povratna informacija (specifična oziroma analitična) med procesom učenja usmerja učence in vsakemu pomaga, da doseže tisto raven dosežkov, ki jo zmore. Zato pravimo, da ima dobra povratna informacija formativno vlogo«. (Razdevšek-Pučko 1999: 149).

Povratne informacije, ki jih dajejo rezultati preverjanja, običajno v obliki ocene, pa so koristne učencem, učitelju in tudi staršem. Učencu predstavljajo vpogled $v$ njegove dosežke (kaj že obvlada in česa še ne) in v učne zmožnosti. Pri promociji 
znanja kot vrednote, je smiselno, da učitelj učencem rezultate preverjanja predstavi tako, da jih razumejo kot pripomoček k izboljšanju svojega dela, saj mu pokažejo kaj že zna in česa se mora še naučiti. S pomočjo rezultatov učenec lahko usmerja svoje nadaljnje delo. Če niso zadovoljivi, lahko poveča samo čas učenja ali pa tudi način in pristop k učenju. (Razdevšek-Pučko 1999: 149; Marentič Požarnik 2000: 261). Marentič Požarnikova pravi, da naj se ta funkcija povratne informacije pri starejših, zrelejših učencih povezuje s samopreverjanjem in naj preide $\mathrm{v}$ samouravnavanje učenja (prav tam). Učitelju naj bi povratna informacija ob končanem preverjanju znanja pomagala pri oblikovanju nadaljnjega dela, v katerega lahko vključi tudi učence. S tem ko jim da določeno mero avtonomije, bo povečal njihovo motivacijo za učenje. Preverjanje znanja oz. ocenjevanje je samo po sebi močno motivacijsko sredstvo, spodbuda za učenje. Vprašljiva je le kvaliteta pridobljenega znanja.

»Učenci jemljejo ocene ne le kot informacijo o dosežkih, ampak tudi o lastnih zmožnostih. S tem postane ocena ena od osnov za samopotrjevanje oziroma oblikovanje samopodobe« (Marentič Požarnik 2000: 261).

Puklek Levpušček in Zupančič (2009) navajata pomen povratne informacije pri razvoju stvarno zaznane učne učinkovitosti: »Povratne informacije odraslih (učiteljev, staršev) so ponavadi tiste, ki pomagajo pri izboljšanju uvida v uspešnost učenčevega dela. (...) Pravilno posredovane povratne informacije iz socialnega okolja so navadno tiste, ki lahko podprejo zaupanje v lastno učno delo in s tem prispevajo tudi $\mathrm{k}$ motivaciji za učenje in pozitivnemu odnosu do šole in šolanja na splošno « (Puklek Levpušček in Zupančič 2009: 64).

Puklek Levpušček in Marentič Požarnik (2005 v Puklek Levpušček in Zupančič 2009: 65) sta izdelali priporočila pravilno posredovanih povratnih informacij, ki spodbujajo razvoj zaznane učne samoučinkovitosti. Pomemben je način, kako odrasli, oz. pomembni drugi učencu posredujejo povratne informacije o njegovem delu in uspešnosti in sicer:

Opis pozitivnih vidikov učenčevega dela: »Pri pisanju eseja o ustvarjalnosti mi je bilo všeč, da si zelo jasno opisal faze ustvarjalnega procesa.«

Konkretizacija napake ali vedenja: »Pri pisanju eseja o ustvarjalnosti nisi navedel ustreznega primera ustvarjalnosti v vsakdanjem življenju.«

Analiza motečega vedenja ali opis napak pri nalogi (ne pa kritika učenčeve osebnosti): »Moti me, da se med poukom obračaš in klepetaš s sošolko.«

Usmeritev povratne informacije v vedenje ali zmožnosti, ki so pod učenčevim nadzorom in na katere lahko vpliva: »Svoje pisalne zmožnosti bi lahko izboljšala z vsakodnevnim pisanjem osebnega dnevnika.«

Spodbujanje prizadevanja in vztrajnosti pri učenju: »Prepričana sem, da boš z rednim pisanjem domačih nalog bolje razumel matematično snov.«

Puklek Levpušček in Zupančič (prav tam) predlagata: »Časovno naj bo povratna informacija (pozitivna ali negativna) blizu dogodku, o katerem govorimo, upoštevamo pa tudi trenutno situacijo, pripravljenost učenca, da posluša, in njegovo »kapaciteto za povratno informacijo. $V$ povratni informaciji posredujemo informacijo o učenčevem napredku v primerjavi z njegovo prejšnjo ravnjo znanja, spretnosti ali učne uspešnosti. Izogibamo se primerjavi z ostalimi učenci. Preverimo, ali je učenec razumel naše sporočilo, in mu damo možnost, da sodeluje $\mathrm{v}$ 
razpravi. Spodbudimo ga, da razmišlja o svojem načinu učenja, doživljanju naloge, zmožnostih, ki jih ima in bi jih lahko uporabil pri izboljšanju svoje učne učinkovitosti, ter mu dajemo možnost, da sam izbira alternative za reševanje problema.«

\section{UČITELJEV VPLIV NA UČNO USPEŠNOST UČENCEV}

Na podlagi pregleda raziskav avtorici (Puklek Levpušček in Zupančič 2009: 65-68) ugotavljata zmerno pozitivno povezanost med učenčevo zaznano samoučinkovitostjo in učno uspešnostjo. Na splošno so učenci z bolj pozitivnimi prepričanji o sebi tudi učno bolj uspešni. Ker je bila potrjena Bandurina predpostavka, da niso le pretekli učni uspehi in učenčeve sposobnosti tisti dejavniki, ki prispevajo h kasnejši učni uspešnosti, ampak se lahko učna uspešnost učencev spreminja tudi v skladu z doživljanjem sebe v učnem okolju, avtorici predlagata, da se v šoli izvajajo programi, ki so usmerjeni v razvijanje pozitivnega odnosa učencev do lastnih učnih zmožnosti v okviru realnega. Učitelj ima pri tem pomembno vlogo, saj $z$ načinom vodenja razreda in komunikacije $z$ učenci lahko krepi pozitivne predstave in prepričanja o delu učencev, o njihovi učni učinkovitosti in uspešnosti pri učenju. Avtorici predlagata, da učitelj s pristopi poučevanja učence usmerja k obvladovanju učne snovi in razvoju lastnih potencialov in zmožnosti ter odsvetujeta primerjave med učenci na področju učnih dosežkov. »Individualiziran pristop k učencu zahteva od učitelja dobro poznavanje učenčevih trenutnih zmožnosti, njegovega predznanja, učnih strategij, učenčevih prepričanj o tem, kaj zmore in kakšne cilje si postavlja pri učenju. Poznavanje individualnih značilnosti učenca učitelju omogoči, da temu prilagaja učno delo. Učitelj pomaga učencu postavljati učne cilje, ki jih bo s prizadevnostjo zmogel doseči. Doživljanje obvladovanja in uspešnosti pri konkretnih nalogah učence opogumlja k postavljanju višjih ciljev in $\mathrm{k}$ večji prizadevnosti pri naslednjih nalogah.«(Puklek Levpušček in Zupančič 2009: 67).

Glede težavnosti nalog svetujeta pripravo nalog, ki učencem predstavljajo izziv, ki utrjujejo in izboljšujejo zaznano raven učne samoučinkovitosti. Naloge ne smejo biti ne prelahke ne pretežke, da učenec lahko izkaže že usvojeno znanje in da ga izzivajo k razmišljanju o problemu, ki ga še ni reševal, vendar bi to zmogel $z$ ustreznim predznanjem.

Učiteljem predlagata, naj učencu dajo ustrezno povratno informacijo o pomanjkljivostih v znanju, naj skupaj z njim analizirajo dosedanje načine učenja, ki so privedli do neuspeha in naj ga spodbuja k prizadevnosti, saj lahko $z$ navajanjem na uporabljanje ustreznih učnih strategij premaga trenutne težave. »Bolj kot sam učni rezultat naj učitelja v procesu učenja zanima, kako se je učenec lotil naloge ter koliko prizadevnosti in samostojnega dela je vložil vanjo. Učitelj z izpostavitvijo dejavnikov, ki jih učenec z ustreznim načinom dela lahko premaga (npr. navajanje k uporabi ustreznejših učnih strategij), učencu lahko prepreči, da bi pripisoval vzroke za učno neuspešnost dejavnikom, nad katerimi nima nadzora (npr. nizke sposobnosti in omejitve, ki izvirajo iz okolja). 


\section{OCENA NAJ BI USMERJALA UČENČEVO NADALJNJE DELO}

»Ocenjevanje ne bi smelo biti uporabno v prvi vrsti za razsojanje, razvrščanje ali izključevanje učencev, ampak naj bi jim bilo v pomoč in naj bi utrdilo njihovo vrednost. To napeljuje na sprotno ocenjevanje (De Landsheere 1991: 26). Marentič Požarnik in Peklaj (2002: 8) navajata več namenov preverjanja in ocenjevanja, med pomembnejše uvrščata preverjanje in ocenjevanje kot motivacijsko sredstvo za učenje. Po Ramsdenu povzemata tri glavne namene ocenjevanja študentov, ki so prenosljivi tudi v srednješolsko okolje: ocenjevanje pomaga učencu, da se bo bolje učil; mu sporoča, kako je napredoval in kaj je dosegel; učitelju nudi podlago za odločanje o izboljšavah v njegovem poučevanju (Ramsden 1992, v Marentič Požarnik in Peklaj 2002: 11). Kljub temu ni mogoče preprečiti, da učenci svojega učenja ne bi uravnavali po koledarju pisnih in ustnih preverjanj, pa če jih še tako prepričujemo, da je važno samo znanje in da se učijo za življenje oz. za poklic. Predlagata torej, da učitelj oblikuje sistem preverjanja tako, da se bodo učenci lahko učili poglobljeno in temeljito (Marentič Požarnik in Peklaj, 2002: 32). Naloge morajo biti primerno težavne in naj bi preverjale višje ravni znanja, npr. po šest stopenjski lestvici Bloomove taksonomije izobraževalnih ciljev (Skela 2008: 164-167).

\section{RAZISKAVA}

Raziskava je bila izvedena ob zaključku šolskega leta 2009 / 2010 pri učencih in učenkah francoščine tretjega triletja osnovne šole, ki se francoščine učijo kot tretjega tujega jezika $\mathrm{v}$ obliki izbirnega predmeta in pri dijakih in dijakinjah $\mathrm{v}$ gimnazijskem programu $v$ prvem in tretjem letniku, ki se francoščine učijo kot obveznega tretjega tujega jezika. Vseh 36 anketirancev ima pouk francoščine dve uri tedensko, torej 70 urni letni program.

Kot instrument $\mathrm{v}$ raziskavi je bila uporabljena anketa. Namen anketiranja je bil seznaniti se s trenutnim stanjem, torej ugotoviti, kako učenci doživljajo nekatere sestavine pouka francoščine (s katerimi didaktičnimi prijemi jih učiteljica (de)motivira za učenje, vloga znanja nasproti učenja za ocene, kako učenci doživljajo učiteljičino povratno informacijo, kako doživljajo in vrednotijo pridobivanje pisnih in ustnih ocen) in na podlagi ugotovitev prilagoditi način nadaljnjega dela, predvsem na področju vrednotenja in ocenjevanja znanja $v$ skladu $\mathrm{z}$ novim pravilnikom o ocenjevanju, ki prične veljati v šolskem letu 2010/2011. Anketa je del instrumentov, ki imajo za končni cilj oblikovati posebne pristope za delo pri pouku tujega jezika, saj le-ta ni prisoten v okolju. Pristopi naj bi bili po meri učencev, in naj bi v čim večji možni meri pripomogli k povečanju motivacije za učenje francoščine, ki izhaja iz želje po znanju in ne le iz želje po dobri oceni.

Anketa je sestavljena iz treh delov. $V$ prvem delu so anketiranci odgovarjali na splošna vprašanja, v drugem delu se vprašanja nanašajo na motivacijske vzroke, ki so vplivali na odločitev za vključitev k pouku francoščine, v tretjem, najobsežnejšem delu ankete so anketiranci odgovarjali na vprašanja, ki se nanašajo na pomen znanja in na vlogo vrednotenja znanja in ocenjevanja pri pouku francoščine na 
motivacijo za učenje. Anketiranci so odgovarjali na 34 vprašanj, od tega jih je bilo sedem odprtega tipa.

Učitelji izbirnih predmetov se zavedajo pomena motivacije, saj prevzemajo vlogo promotorjev, oz. oglaševalcev predmetnega področja, in morajo vsako leto »nabrati« dovolj učencev za napolnitev razreda ali skupine. Motivaciji, ki pritegne učence k izbirnemu predmetu, sledi motivacija za učenje in za vztrajnost. Učitelj ima možnost vplivati na odnos učencev do predmeta, zato je smiselno poiskati načine, kako učencem podati realno povratno informacijo o njihovem delu in njihovem napredku, ki bo spodbudna za učenje in za učenčevo osebno rast. Seveda so pri tem pomembne tudi ocene.

\section{REZULTATI RAZISKAVE}

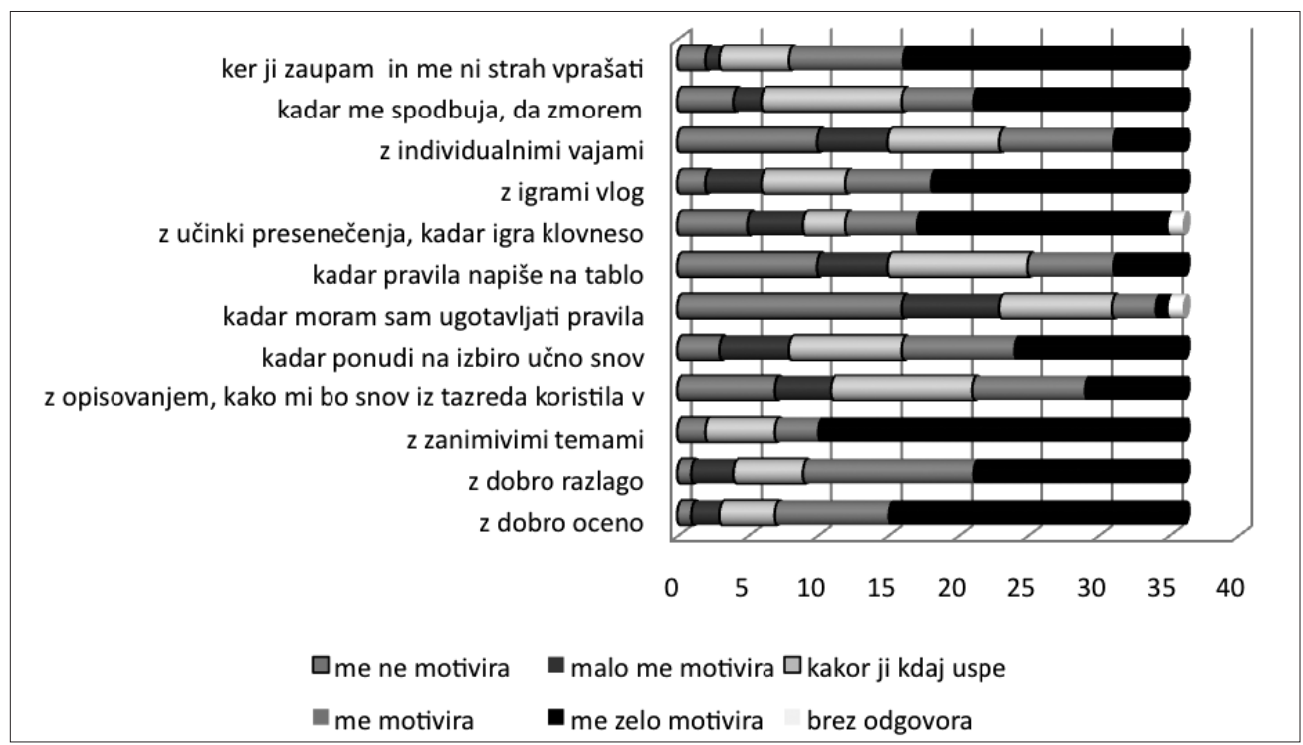

Graf 1: Motivacijski dejavniki, ki učence spodbujajo za delo v razredu. Analiza odgovorov na vprašanje: »Uciteljica me ne motivira, me malo motivira, kakor ji kdaj uspe, me motivira, me zelo motivira«.

Kot je razvidno iz grafa 1 , anketirane učence najbolj motivirajo za delo v razredu zanimive teme, na drugem mestu je dobra ocena, pomemben dejavnik je tudi zaupanje, da učenci lahko vprašajo učiteljico, kar želijo, všeč so jim tudi učinki presenečenja med poukom in igre vlog. Kar nekoliko preseneča, je, da učencev ne motivira za delo v razredu to, da sami ugotavljajo pravila, saj novejše teorije priporočajo induktivni pristop k poučevanju, torej »učenje po principu odkrivanja« (Židan: 5).

Po drugi strani pa anketa razkriva, da je pri francoščini znanje pomembnejše od ocene, in sicer $11 \%$ vprašanih se pri francoščini uči za dobro oceno, ostalih 89 \% učencev pa pravi, da je znanje pomembnejše od ocene. Razlago lahko poiščemo v dejstvu, da si učenci v osnovni šoli sami izberejo ta predmet izmed mnogih po- 
nujenih izbirnih predmetov, na gimnaziji pa se zanj odločijo med dvema ponujenima tujima jezikoma, izbira je torej nujna. Začetno željo po znanju je potrebno negovati skozi ves čas šolanja, tudi zato, da učenec nadaljuje $z$ učenjem jezika še po končanem šolanju, $v$ formalnem ali neformalnem izobraževanju. Kot pravi Gardner (2000), je pomembno mladim dati model za najbolj odločilne sposobnosti, med katerimi navaja ljubezen do učenja, saj tudi to potrebujejo, da bodo opravili življenjski test.

Glede na pridobljene rezultate na vprašanje: »Po mojem mnenju moje znanje ustreza oceni«, učenci smatrajo, da njihovo znanje ustreza pridobljeni oceni (66\%), $14 \%$ se ne strinja $z$ razmerjem znanje:ocena, $20 \%$ tega ne zna oceniti. $97 \%$ učencev meni, da so bili v tem šolskem letu pošteno ocenjeni, ostali (3\%) pa menijo obratno.

Bolj iz radovednosti kot iz namena po spremembi količinskega preverjanja znanja, je bilo učencem zastavljeno vprašanje: »Obkroži. Šolske naloge so: preredke, prepogoste, dve sta ravno prav«. Iz analize je razvidno, da se večina učencev ( 84 \%) strinja $z$ dvema šolskima nalogama, kot je predvideno v Pravilniku o ocenjevanju znanja v srednji šoli. Še vedno pa nekateri (12\%) menijo, da bi moralo biti več pisnih preverjanj znanja, sklepamo da ta skupina učencev potrebuje zunanjo spodbudo za učenje in dobro je, da se tega zaveda. 4 \% vprašanih se zdi, da so pisna preverjanja prepogosta.

Kar je pomemben podatek za nadaljnje delo, je pokazatelj kvalitete šolskih nalog. Na lestvici smiselne (44\%), težke (20\%), dolgočasne (18\%), nesmiselne (9\%), lahke (6\%), drugo: ne vem (3\%) rezultati kažejo na relativnost dojemanja kvalitete šolskih nalog, pa vendar je rezultat jasno opozorilo učiteljici, da mora v šolske naloge vnesti več zanimivosti oziroma izzivov (McKay 2005). Kontrolno vprašanje glede težavnosti razkriva, da so šolske naloge le trem učencem od enaindvajsetih, ki so podali dodatno pojasnitveno mnenje, "včasih malo pretežke«, ostali pojasnjujejo: »šolske naloge so dobro sestavljene, ker vsebujejo vse elemente, ki smo se jih učili«, »so rešljive in zajemajo preizkus o znanju, ki smo ga dobili v šoli«.

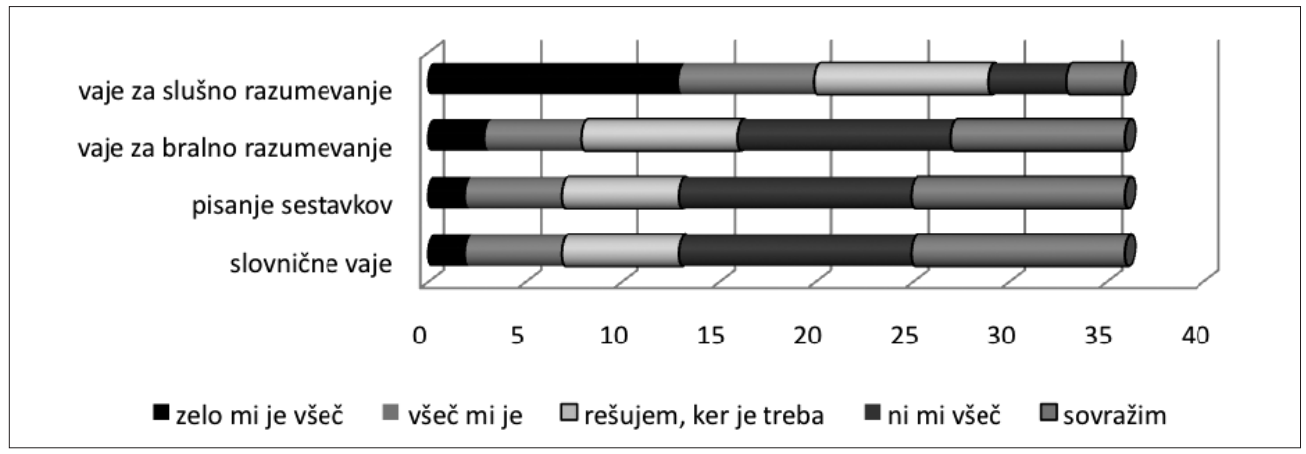

Graf 2: V̌rečnost vsebine šolskih nalog

Kljub temu, da bodo šolske naloge še vedno preverjale slušno in bralno razumevanje, znanje slovnice in spretnosti pisnega izražanja, ne glede na odgovore učencev, je iz grafa 2 razvidno, da učenci najraje rešujejo vaje za slušno razumevanje, pri katerih so običajno zelo uspešni. Odgovori na to vprašanje v povezavi $z$ 
odgovori, ki se nanašajo na kvaliteto šolskih nalog, odkrivajo učiteljici dejstvo, da večina učencev ni zadovoljna $z$ vajami $v$ šolskih nalogah, torej napotek da naj jih izboljša, dodela, osmisli, naredi bolj zanimive. »Raziskave dokazujejo, da učenci lahko izgubijo motivacijo, če so njihove naloge prelahke« oziroma če ne vključujejo dovolj izzivov za reševanje (De Landsheere 1991: 26; McKay 2005).

Anketiranci so odgovarjali na vprašanje: »Obkroži: a. Ker se sproti učim, dovolj znam, da se pred šolsko nalogo sploh nič ne učim. b. Pred šolsko nalogo ponovim snov v ne več kot treh urah in sem zadovoljen s svojim znanjem c. Pred šolsko nalogo se naučim vse potrebno v ne več kot petih urah d. Pred šolsko nalogo se učim več kot pet ur in še vedno imam občutek, da »nimam pojma«.

Analiza kaže, da polovica učencev pred šolsko nalogo ponovi snov v ne več kot treh urah in je zadovoljna s svojim znanjem. $20 \%$ učencev se, zahvaljujoč sprotnemu učenju, pred šolsko nalogo sploh nič ne uči, ker dovolj znajo, 19\% se pred šolsko nalogo nauči vse potrebno v ne več kot petih urah, ostalih $11 \%$ pa se pred šolsko nalogo uči več kot pet ur in ima še vedno občutek, da »nima pojma«.

\section{GOVORNI NASTOPI ZA OCENO}

Graf kaže, da obstoječi način pridobivanja ustnih ocen $z$ govornimi nastopi v veliki meri ustreza učencem. Najbolj pozitivno ocenjujejo, da ga lahko pripravijo s sošolcem ali sošolko, nadalje, da je tema le okvirno določena, da izdelek pred nastopom oddajo v učiteljici branje in da so samostojni pri delu. Ni jim všeč dejstvo, da priprava govornega nastopa vzame preveč časa, še posebej, kadar pripravljajo video posnetke. Kljub temu želijo, da ta sistem ostane. Kar preseneča je, da si večina učencev želi imeti dogovorjeno spraševanje, torej točno določen termin, kdaj bodo svoj nastop pokazali. Med predlogi za izboljšanje pridobivanja ustnih ocen $\mathrm{z}$ govornimi nastopi ni bilo konkretnih predlogov ob dejstvu, da je posameznikom omogočeno pridobiti ustno oceno na klasičen način, torej s spraševanjem.

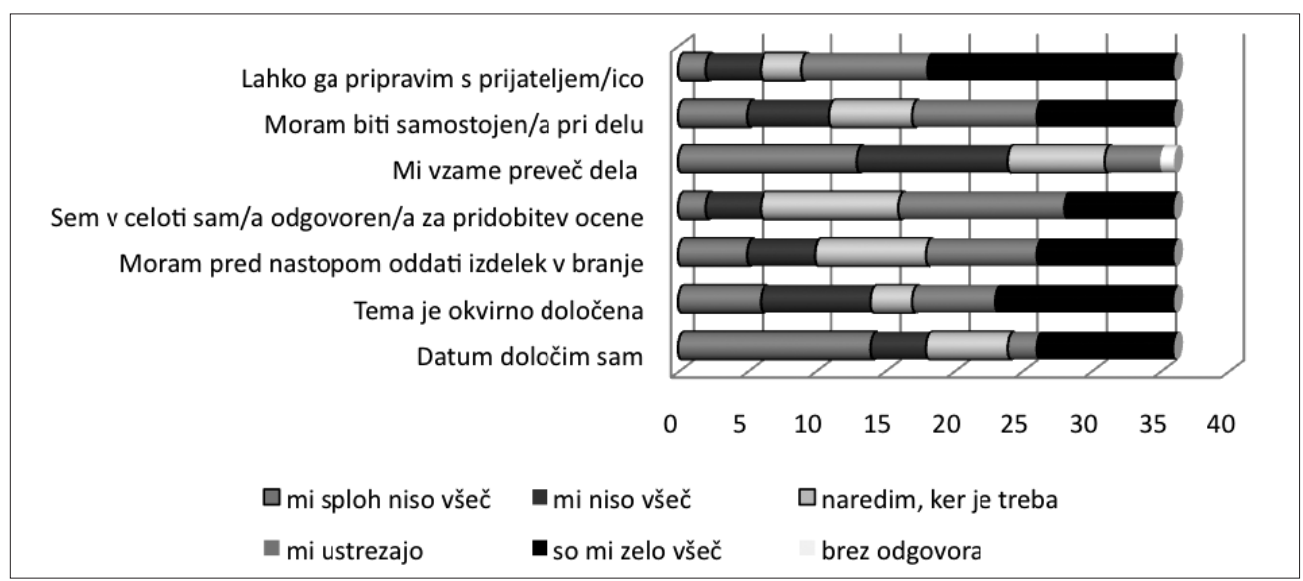

Graf 3: Govorni nastopi za oceno. Anketiranci so odgovarjali na vprašanja o govornib nastopib na pet stopenjski lestvici, od »mi niso v̌̌eč ker«, do »so mi zelo v̌́eč ker«. 


\section{SPODBUDNI DEJAVNIKI PRI POUKU ZA UČENJE FRANCOŠČINE}

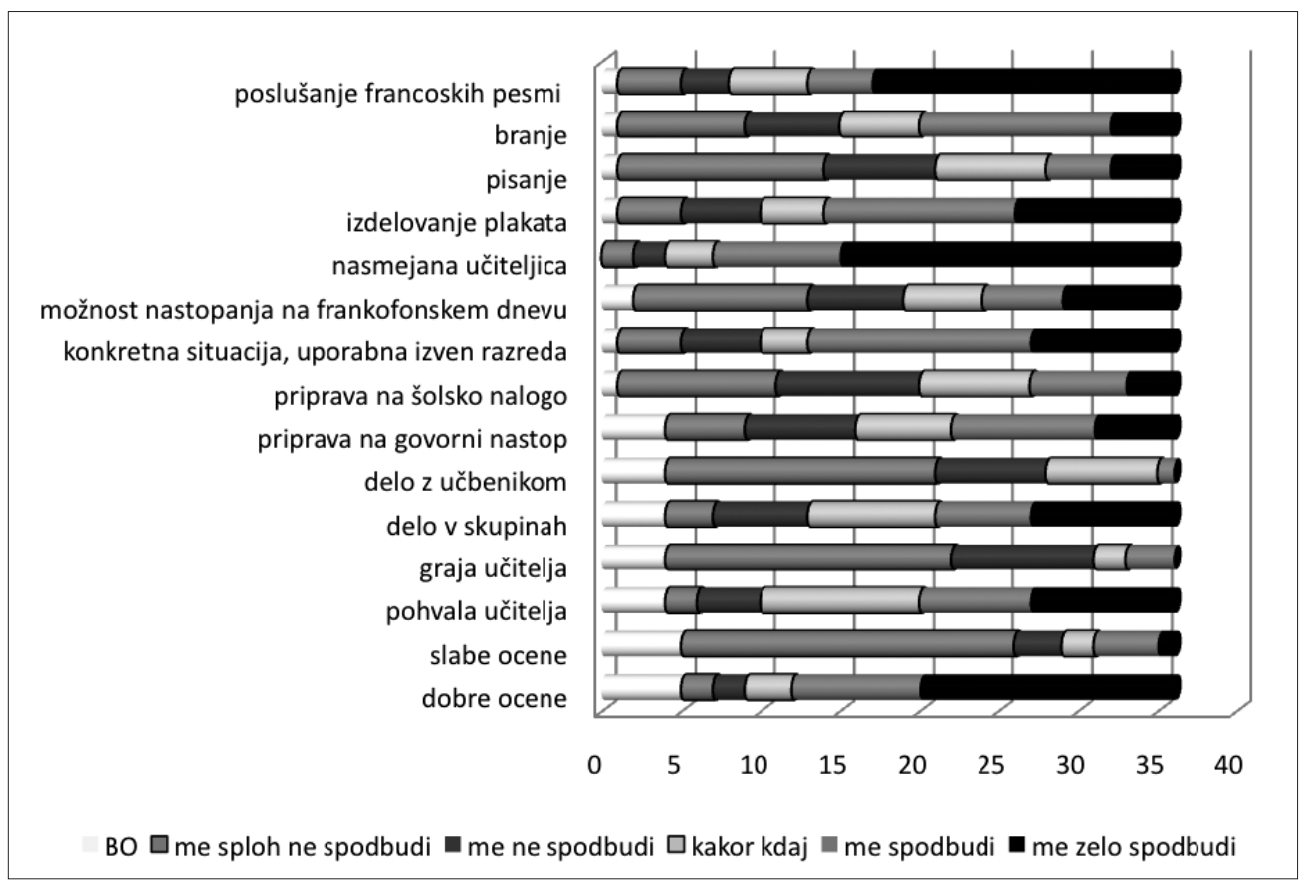

Graf 4: Dejavniki, ki pri pouku francoščine najbolj spodbudijo željo po znanju tega jezika. Odgovori na vprašanje: Na pet stopenski lestvici označi: učiteljica me za delo v razredu splob ne motivira, me ne motivira, kakor kdaj, me motivira, me zelo motivira.

Iz grafa 4 je razvidno, da izmed naštetih dejavnikov, ki se iz različnih vidikov nanašajo na pouk francoščine, motivacijsko najbolj pozitivno deluje nasmejana učiteljica, dobre ocene, poslušanje francoskih pesmi in aktivnosti, ki spominjajo na avtentične situacije, uporabne izven razreda, ter izdelovanje plakata. Spodbudno delujejo tudi pohvala učitelja, bralne aktivnosti, delo v skupinah in priprava na govorni nastop. Med najbolj nespodbudnimi so slabe ocene, graja učitelja in delo $\mathrm{z}$ učbenikom, pa tudi produktivna aktivnost pisanja. Na tem mestu bi bilo smiselno, da učiteljica večkrat poudari, da $z$ urjenjem teh zmožnosti učencem daje moč. Podatek, ki bode $v$ oči je, da priprava na šolsko nalogo pri večini učencev ne spodbuja želje po znanju francoščine.

Kot je razvidno iz celotne ankete, kaže večina odgovorov na potrebo po izboljšanju strukture šolskih nalog oz. razmislek, da pisno oceno pridobljeno s šolsko nalogo zamenja drugačna oblika preverjanja, ki bi bila bolj skladna z načinom dela $\mathrm{v}$ razredu (projektno delo, medpredmetne povezave, timsko poučevanje). 


\section{KAKO UČENCI DOJEMAJO NEFORMALNA SPOROČILA SVOJE UČITELJICE}

Rezultati kažejo, da pozitivna povratna informacija v veliki meri (74\%) pozitivno vpliva na motivacijo učencev za učenje francoščine. $10 \%$ učencev spodbudi k učenju negativna povratna informacija, trije odstotki nočejo povratne informacije, $13 \%$ učencev ne ve, kaj želi, ostali niso odgovorili na vprašanje. Rezultat bi bil zagotovo drugačen, če bi bilo v raziskavi dajanje povratne informacije razdeljeno na javno, pred razredom in na zasebno, individualno. Tretjina učencev torej javno povratno informacijo preprosto presliši, ker nočejo biti izpostavljeni. Če želijo dodatne pojasnitve ali pogovor potrebujejo individualni pristop.

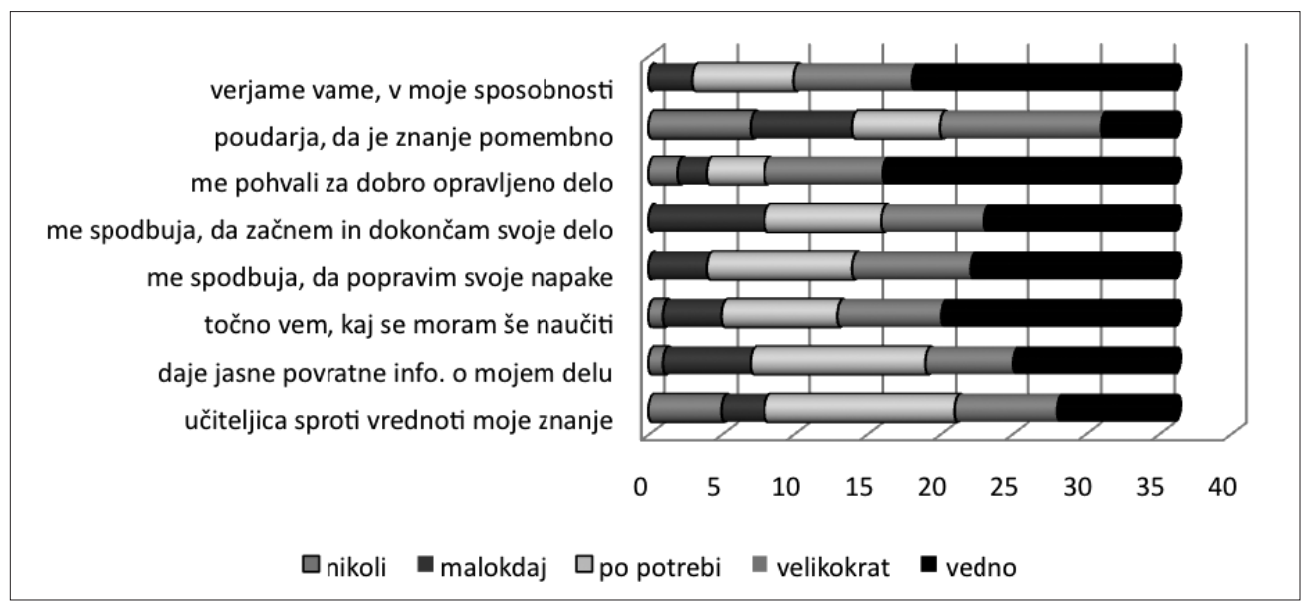

Graf 5: Kako učenci doživljajo učiteljičine namere razvijanja pozitivnega odnosa učencev do lastnib učnih zmožnosti. Odgovori na vprašanje: Razvrsti trditve na pet stopenjski lestvici, od najmanj pomembno (1) do zelo pomembno (5).

Iz grafa 5 je razvidno, da je bila učiteljica, po ocenah učencev, najbolj uspešna pri pohvali za dobro opravljeno delo, da so učenci opazili delovanje v smeri realnih spodbud, iz sprotnih povratnih informacij znajo razbrati, česa se morajo še naučiti, hkrati razumejo spodbudo za popravilo napak in spodbudo, da dokončajo svoje delo. Kljub dobrim namenom, rezultati kažejo na razhajanje med podajanjem in razumevanjem podanih sporočil učencem in tako opominjajo, da je potrebno izboljšati način sprotnega vrednotenja znanja, predvsem jasnost povratnih informacij o delu učencev, ter jasneje in bolj pogosto poudarjati, da je znanje pomembno.

Ugotovitve ameriških raziskovalk (Mueller in Dweck 1998, str. 33, 48, 49, 50) ki temeljijo na podlagi šestih študij kažejo, da ima na motivacijo in učno storilnost učencev boljši učinek poudarjanje truda (»trdega dela«), kot pa poudarjanje sposobnosti (inteligence). Motivacijo za doseganje ciljev najbolj uspešno spodbuja pohvala učenčevih delovnih navad in strategij pri delu (učenju, reševanju problemov) po uspešnem zaključku naloge. Učenci v skupini, kjer je bil pomemben trud so se odločali za naloge, ki so obetale več učenja, z željo po informacijah o 
strategijah dela so izkazovali kontinuiran interes za pridobivanje spretnosti, cenili so priložnosti za učenje, svoj neuspeh so pripisali premajhnemu trudu. Pri tej skupini je bilo zaznano večje veselje in večja vztrajnost pri reševanju nalog, inteligenco so si razlagali $z$ besedama motivacija in znanje.

Glede pričakovanj učiteljice pri pouku francoščine, polovica učencev ocenjuje, da kakor kdaj, 28\% meni, da ima učiteljica previsoka pričakovanja, $11 \%$ tega sploh ne opazi, $2 \%$ vprašanih menita, da ima prenizka pričakovanja, nihče pa ni ocenil, da je učiteljica brez pričakovanj. V rubriki »drugo « $3 \%$ menijo, da so pričakovanja ravno prava, $3 \%$ ne vedo, kakšna pričakovanja ima njihova učiteljica in 3\% učencev na vprašanje niso odgovorili.

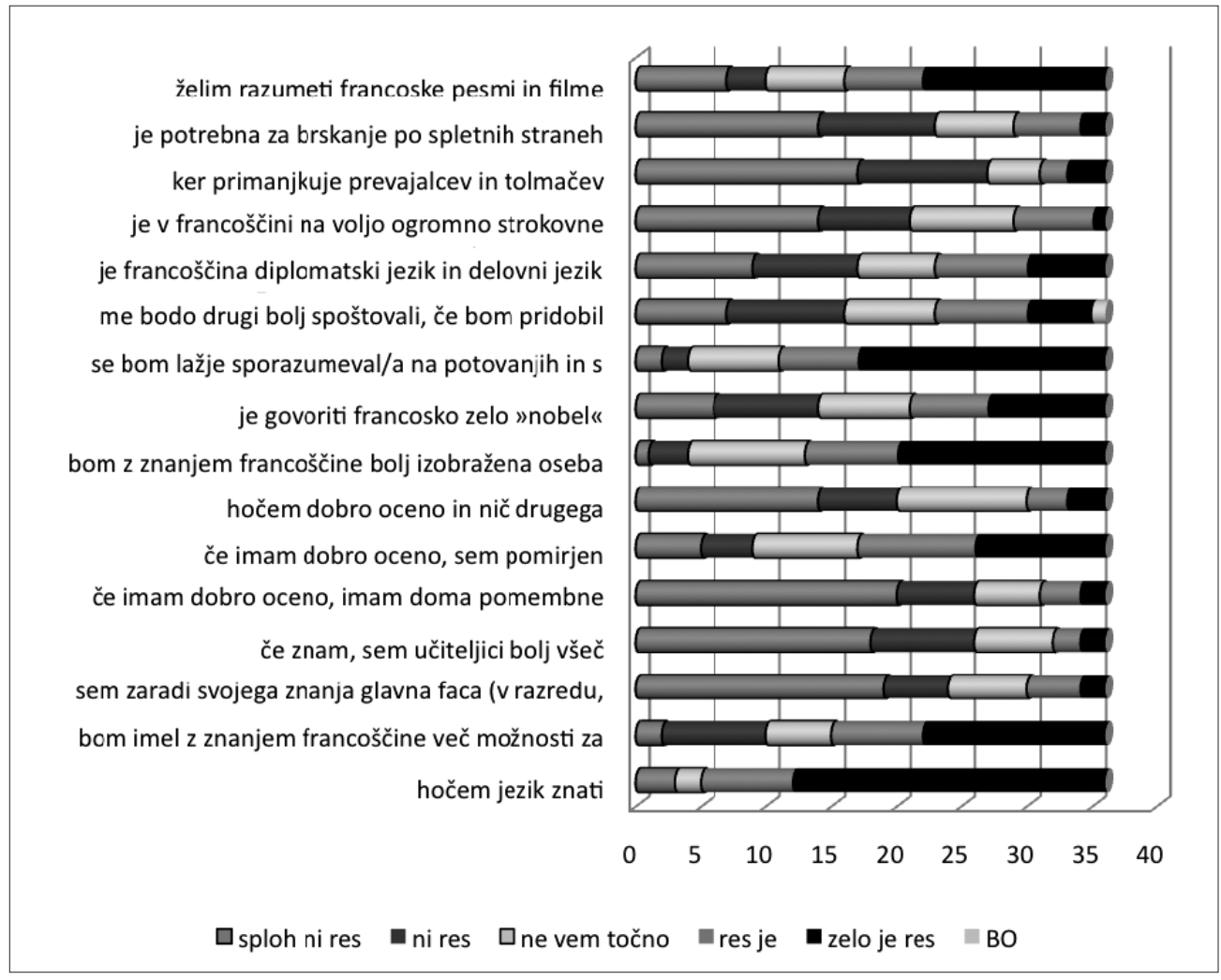

Graf6: Vzroki za učenje francoščine

Iz odgovorov na vprašanje: »Razvrsti trditve od najmanj pomembno (1) do zelo pomembno (5): francosko se učim, ker... « je nastal graf 6, ki omogoča vpogled $v$ vzroke za učenje francoščine, ki so dobra podlaga za pripravo takih šolskih aktivnosti, ki bodo spodbujale poglobljeno učenje francoščine. Zelo težko bo pripraviti primerno zahtevne naloge, ki bodo $\mathrm{v}$ razredih, ki so izjemno heterogeni kar zadeva raven znanja, delovale spodbudno in bodo vzdrževale visoko stopnjo motivacije za učenje francoščine, torej željo po znanju. 


\section{ZAKLJUČEK IN DISKUSIJA}

Ocene po predmetih zagotovo niso primerljive na državni ravni. Zanimivo bi bilo narediti primerjavo šolskih nalog vseh učiteljev/ic v Sloveniji, ki poučujejo isti predmet, npr. francoščino za preverjanje znanja iste tematike. Seveda so spremembe v sestavi šolskih nalog tudi pri posameznih učiteljih, gledano kronološko, torej $\mathrm{v}$ primerjavi s prvimi leti poučevanja in kasneje. Poučno bi bilo raziskati, kako učitelji rešujejo zagate glede različnega predznanja, npr. ob prehodu iz osnovne šole v srednjo šolo, saj se dogaja, npr. pri tujih jezikih, da je v razredu polovica učencev začetnikov, druga polovica pa ima zelo razpršeno znanja, od učencev, ki so tri leta resno delali v osnovni šoli, do tistih, ki so se francoščine učili površno le eno leto. Posledično se mora nujno zgoditi, da ocene niso več strogo primerljive z nivojem znanja na razredni ravni, tudi zato ne, ker učenci ob začetku šolskega leta nimajo enakega predznanja, ampak so odraz učenčevega osebnega napredka, ki je odraz njegovega dela in posledica njegovega odnosa do znanja.

Analiza lastnega delovanja $v$ razredu učitelju omogoča realen vpogled v njegovo delo $z$ vidika učencev in mu omogoča, da ob upoštevanju mnenj spozna doživljanja svojih učencev v času, ki ga preživijo skupaj in tudi, da na podlagi pridobljenih rezultatov izboljša svoje delo, svoj pristop k delu, način komunikacije, podajanja povratnih informacij, vodenja razreda, nenazadnje pridobi povratno informacijo glede načina svojega ocenjevanja, učencem lahko da možnost, da podajo svoja mnenja glede načinov pridobivanja ocen in jim po lastni presoji omogoči sooblikovanje pouka in/ali ocenjevanja.

Vsak učitelj bi moral najprej spoznati razred, nato vsakega učenca in prisluhniti njegovim potrebam. Ker je to v praksi težko vsesplošno izvedljivo, že zato, ker nimajo vsi učitelji enakih zmožnosti vživljati se $\mathrm{v}$ druge in jih znati poslušati, razumeti, je za začetek smiselno že to, da se učitelj odloči, da so vsi učenci sposobni napredka in da si pripiše sposobnost, da jim bo pri tem pomagal, jih spodbujal. Pri pouku, če je mogoče tudi izven njega in seveda s spodbujanjem staršev k vključevanju v delo in življenje na šoli. Ker je to za učitelja zahteven in dolgotrajen proces, se bo za lastno evidenco in $z$ namenom izboljšati svoje delo, ob koncu šolskega leta na primeren način pozanimal o zadovoljstvu učencev $z$ njegovim načinom dela in analiziral svoje delo skozi oči učencev in /ali njihovih staršev, mogoče tudi svojih sodelavcev/kolegov.

\section{LITERATURA}

ČOK, Lucija/Janez SKELA/B. KOGOJ/C. RAZDEVŠEK-PUČKO (1999) Učenje in poučevanje tujega jezika. Ljubljana: Pedagoška fakulteta in Koper: Znanstvenoraziskovalno središče RS.

De LANDSHEERE, Gilbert (1991) General Issues Relating to Pupil Achievent. V: P. WESTON (ur.), Assessement of Pupil Achievement: Motivation and School Success - report of the educational research workshop held in Liège 12-15 september. Council of Europe-Strasbourg: Swets\& Zeitlinger, 19-29. 
GARDNER, H. (2000) What do Tests Test?. 30. julij 2010. http://www.educationworld.com/a_issues/issues098.shtml.

GINSBURG, Golda S./ Phyllis BRONSTEIN (1993) Family Factors Related to Children's Intrinsic/Extrinsic Motivational Orientation and Academic Performance. Child Development 64, 1461-1474.

GROLNICK, Wendy S./ Maria L. SLOWIACZEK (1994) Parent's Involvement in Children's Schooling: A Multidimensional Conceptualization and Motivational Model. Child development, 65, 237- 252.

KALIN, Jana/ Metod RESMAN/Barbara ŠTEH/Petra MRVAR/ Monika GOVEKAR-OKOLIŠ/Jasna MAŽGON (2009) Izzivi in smernice kakovostnega sodelovanja med šolo in starši. Ljubljana: Znanstvenoraziskovalni inštitut Filozofske fakultete.

MARENTIČ POŽARNIK, Barica (2000) Psihologija učenja in pouka. Ljubljana: DZS.

MARENTIČ POŽARNIK, Barica/Cirila PEKLAJ (2002) Preverjanje in ocenjevanje za uspešnejši študij. Ljubljana: Center za pedagoško izobraževanje Filozofske fakultete.

McKAY, Penny (2005) Assessing Young Language Learners. Cambridge: Cambridge University Press.

MUELLER, Claudia M./Carol Susan DWECK (1998) Praise for Intelligence Can Undermine Children's Motivation and Performance. Journal of Personality and Social Psychology 75, 1, 33-52.

PUKLEK LEVPUŠČEK, Melita/Maja ZUPANČIČ (2009) Osebnostni, motivacijski in socialni dejavniki učne uspešnosti. Ljubljana: Center za pedagoško izobraževanje Filozofske fakultete.

SKELA, Janez (2008) Vrednotenje učbenikov angleškega jezika z vidika kognitivne teoorije učenja (154-178). J. Skela (ur.), Učenje in poučevanje tujib jezikov na Slovenskem: pregled sodobne teorije in prakse. Ljubljana: Tangram.

ŽIDAN, Alojzija. 30. julij 2010. http://www.verbic.org/doc/zt/Zidan-sem.pdf.

POVZETEK

\section{Vloga učitelja pri učni uspešnosti učenca: primer francoščine kot tretjega tujega jezika}

Učna uspešnost učencev, učenk, dijakov in dijakinj (nadalje učencev) je odvisna od mnogih dejavnikov, notranjih in zunanjih, med katerimi so tudi taki, na katere imajo lahko pomemben vpliv učitelji in starši. Vprašanje je, ali učitelj zna oz. vsaj skuša odgovoriti na vprašanje: Kaj lahko jaz, kot učitelj naredim, da bodo učenci (pri mojem predmetu) učno uspešnejši? V prvem delu prispevka je izpostavljenih le nekaj možnosti iz obstoječe literature (predvsem slovenskih avtorjev), ki jih ima učitelj na razpolago, da pozitivno vpliva na učenčev razvoj, na njegov odnos do dela v šoli, na njegovo učno uspešnost. V drugem delu je predstavljena analiza ankete, ki je bila izvedena ob zaključku šolskega leta $v$ sodelovanju $\mathrm{z}$ učenci francoščine, $\mathrm{z}$ namenom, da bodo na podlagi pridobljenih rezultatov, 
učiteljevi pristopi v razredu (vodenje razreda, sodelovanje s starši, komunikacija $z$ učenci, struktura in težavnost nalog, nudenje ustrezne povratne informacije, preverjanje znanja) pripomogli k povečanju notranje motivacije za učenje francoščine.

Ključne besede: učna uspešnost, motivacija, povratna informacija, ocenjevanje, preverjanje znanja

\section{ABSTRACT \\ Teachers's role in pupil's learning achievement: an example of French as third foregin language}

Pupils' success in learning depends on many inner and outer factors, among which are those on which teachers and parents have a very important influence. The dilemma therefore is whether the teacher knows how to improve the pupils's work. In the first part of this article we laid out several possibilities available to the teacher from the current practice which have a positive influence on pupil's development, on his/her attitude towards school work and on his/her success in learning. In the second part we presented the survey analysis that was carried out at the end of the school year among French language learners. The findings of this research can help the teacher improve different approaches in the classroom (leading the students, cooperation with parents, comunication with pupils, the structure and the level of difficulty of the exercices, offering the appropriate feedback, evaluation and assessement) with a view to increase internal motivation for learning French.

Keywords: success in learning, motivation, feedback, evaluation, testing 